\title{
THE ACTION OF PROLYL-LEUCYL-GLYCINAMIDE (PLG) ON THE NIGROSTRIATAL PATHWAY OF THE RAT
}

\author{
JOAO S. PEREIRA ****-LUIZ AUGUSTO F. ANDRADE** \\ PAULO H.F. BERTOLUCCI*** - J. GERALDO CAMARGO LIMA* \\ HENRIQUE B. FERRAZ****
}

\begin{abstract}
SUMMARY - In order to study the nigrostriatal pathway, we obtained the rotatory behavior model in male Wistar rats by electrolytic lesion of the left lateral hypothalamic region. Animals thus lesioned displayed rotations toward the same side of lesion when apomorphine was administered, a result in disagreement with what has been obtained in the model with 6-hydroxydopamine lesion. The administration of PLG alone was not followed by rotatory behavior but when the compound was administered in low doses $(0.25$ to $1 \mathrm{mg} / \mathrm{kg})$ simultaneously with apomorphine to animals previously submitted to REM sleep deprivation, a significant increase in the number of rotations was observed in comparison with controls and groups receiving higher doses of PLG. These results indicate that PLG may act as a modulator on dopamine receptors in the striatum.
\end{abstract}

\section{Agio de prolil-leucil-glicinamida (PLG) na via nigroestriatal do rato.}

RESUMO - No intuito de estudar a via nigroestriatal, produzimos uma lesão na região hipotalârnica lateral de ratos Wistar. Os animals passavam a apresentar comportamento rotatório para o mesmo lado da lesão. A administraçăo isolada do PLG não induziu o comportamento rotatório. Entretanto, com doses baixas do composto, concomitantemente à administração de apomorfina em animais previamente submetidos à privacão de sono REM, observou-se aumento no número de rotacões quando comparado ao grupo controle a aos grupos aue receberam doses altas de PLG. Estes achados sugerem que o PLG age como um modulador sobre as receptores dopaminergicos do estriado.

The observation that melanocyte stimulating hormone (MSH) has a deleterious effect on Parkinson's disease 13 was the start point for a series of investigations, both experimental $7,21,23,24,33$ and clinical $4,5,16,17,20$ of the effects of a synthetic tripeptide, prolyl-leucyl-glycinamide (PLG) on Parkinson's disease. The rationale for these studies is that PLG shares many properties with the melanocyte inhibiting factor (MIF). The investigations mentioned showed that PLG may be useful in Parkinson's disease, a benefit that may be enhanced by association with dopaminergic agonists.

These studies, however, did not clarify the mechanism of action of PLG, so that we decided to further investigate on this issue, by studing the action of this compound on the rotatory model of the rat 31,32 . It is postulated that the destruction of the nigrostriatal pathway leaves hypersensitized postsynaptic dopaminergic receptors due to denervation. When a dopaminergic agent is administered, the unbalance causes a rotatory behavior, the animal turning toward the same side or contralateral to the lesions, according with its pre or postsynaptic actions.

Division of Extrapyramidal Diseases Investigation, Department of Neurology and Neurosurgery, Escola Paulista de Medicina (São Paulo): *Full Professor of Neurology; ** Associate Professor of Neurology, Head of the Division; *** Associate Professor of Neurology; **** Postgraduate of Neuroloky. Research supported by CNPa, FAPESP and FINEP. 


\section{MATERIAL AND METHODS}

Male albino Wistar rats were used. The animals were 3 to 5 months old, weighted 250 to 350 grams and were kept in steedy conditions of light and temperature, with water and food ad lib. Each animal was anesthesized with methyleugenol 10, 250mg/kg 1.p. A stereotaxically directed lesion was made by the passage of a cathodic current of $2 \mathrm{~mA}$ for 10 seconds in the left lateral hypothalamic region, according to previously described parameters 30. After the surfery the animals were keot in individual cages, and 24 hours later submitted to behavioral observation for selection regarding further experiments. Selection criteria were spontaneous rotation of 3600 and walking in circles, independent of the number of rotations as long as they proceeded in the same direction. On the 7 th day after the surgery, $2 \mathrm{mg} / \mathrm{kg}$ of apomorphine was administered in order to submit the animals to a new selection, using the same criteria described above and observing them up to 30 minutes after the drug. Only animals exhibiting rotatory behavior on this second selection were utilized. PLG was synthesized in the Department of Biophysics of the Escola Paulista de Medicina, and apomorphine was purchased from Sigma Laboratories. Both drugs were diluted in normal saline and infected intra-peritoneally.

In the first series of experiments 6 groups with 5 rats in each were used. On the 15 th day after surgery a control group received saline, and the others recelved PLG in different doses as shown in table 1, followed by observation of rotatory behavioral for 60 minutes. In the second serles of experiments 7 groups with 5 rats in each were used. On the 30 th day after surgery all animals were submitted to REM sleep deprivation (REM SD) by the inverted flower pot technique 1 for 72 hours. Immediately after the REM SD a control group received saline, two other groups 0.25 or $0.50 \mathrm{mg} / \mathrm{kg}$ of apomorphine, and the remaining four groups received different doses of PLG followed by $0.25 \mathrm{mg} / \mathrm{kg}$ of apomorphine as shown in table 2. Then, the animals had their behavior observed for a maximum period of 30 minutes. Once started the rotation behavior, the number of rotations was determined during 10 minutes.

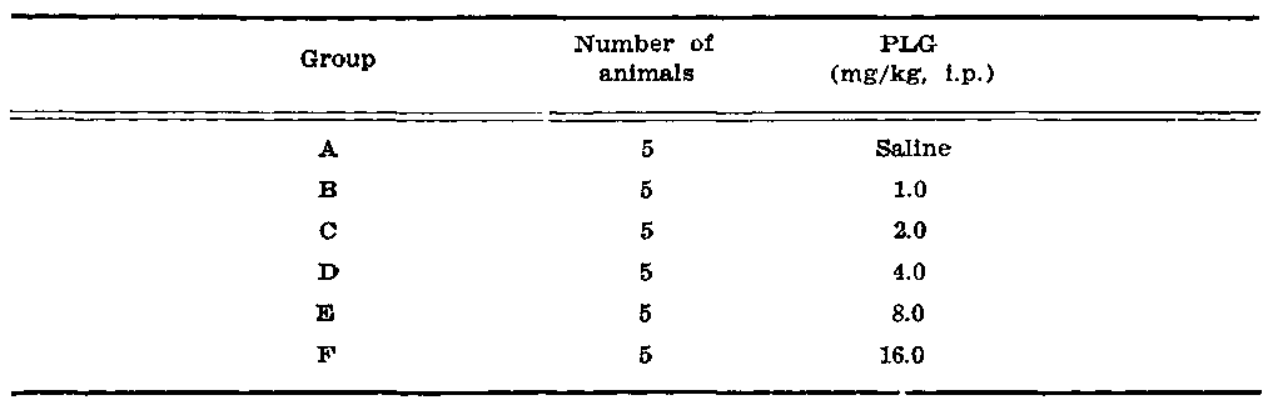

Table 1 - Groups of different doses of PLG and number of animals.

\section{RESULTS}

The rotatory behavior toward the same side of the lesion occurred spontaneousiy for 3 or 4 days after surgery and reappeared after administration of apomorphine in the 7 th day.

In experiment 1 no animal in any of the groups displayed rotatory behavior after administration of PLG. In the groups receiving the highest doses (4, 8 and $16 \mathrm{mg} / \mathrm{kg})$ diminished motor activity was seen, assnciated to sleeniness and plloerection.

In experiment 2 no rotatory behavior was seen in groups $\mathbf{A}, \mathbf{B}, \mathbf{C}$ and $\mathbf{G}$. In groups D. E and $\mathbf{F}$ rotatory behavior was present, with highest number of rotations seen in group E (Table 3).

Analyais of variance showed significant difference among the groups of experiment 2 ( $p<0.05)$. Student $t$ test showed a significant difference $(\underline{p}<0.05)$ when groups $A, B, C$ and $G$ were compared to groups $D$ and E. A difference at the same level was seen when tho last two groups were compared one to the other. No difference was seen when compartag any sroup with group 5 . 


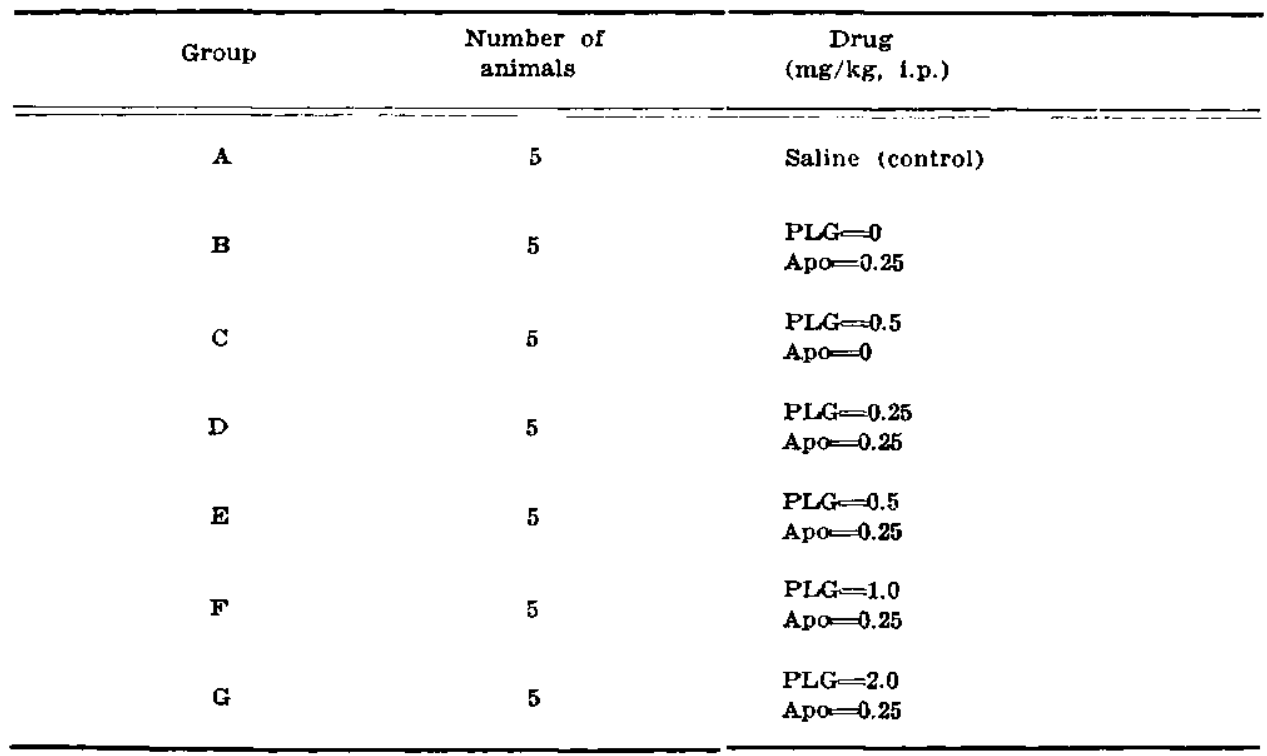

Table 8 - Drug schedule and number of animals for experiment. 2. Apo, apomorphine.

\begin{tabular}{|c|c|c|}
\hline Group & Drugs & $\begin{array}{c}\text { Number of rotations } \\
\text { (mean } \pm \text { SD) }\end{array}$ \\
\hline $\mathbf{A}$ & Saline & o \\
\hline $\mathbf{B}$ & $\begin{array}{l}\text { PLG }=0 \\
\text { ApO=0.30 }\end{array}$ & 0 \\
\hline $\mathrm{C}$ & $\begin{array}{l}\text { PLG }=0.50 \\
\text { Apo }=0\end{array}$ & 0 \\
\hline $\mathbf{D}$ & $\begin{array}{l}\text { PLG }=0.25 \\
\text { Apo }=0.25\end{array}$ & $3.0 \pm 3.5$ \\
\hline $\mathbf{E}$ & $\begin{array}{l}\text { PLG }=0.50 \\
\text { Apo }=0.25\end{array}$ & $31.2 \pm 23 . \varepsilon$ \\
\hline $\mathbf{F}$ & $\begin{array}{l}\text { PLG }=1.00 \\
\text { Apo }=0.25\end{array}$ & $12.6 \pm 17.6$ \\
\hline $\mathbf{G}$ & $\begin{array}{l}\text { PLG }=2.00 \\
\text { Apo }=0.25\end{array}$ & 0 \\
\hline
\end{tabular}

Table 3 - Number of rotations observed in each group $(n=5)$ after injection i.p. of drugs (expcriment 2). $S D$, standard deviation; Apo, apomorphine.

\section{COMMENTS}

Flacing the electrolytic lesion in the lateral hypothalamic region was based in the demonstration of ascending nigrostriatal dopaminergic pathways running near this area 2 . In the model thus obtained the animals displayed rotatory behavior ipsilateral to the lesion, in disagreement with the original model developed by Ungerstedt 31,32 who injected 6-hydroxydopamine in the nigrostriatal pathway for neuronal destruction. An explanation for the difference is that the rotatory behavior is a result of dopa- 
minergic stimulation, both pre and postsynaptic, on the intact side, as demonstrated by previous studies with dopaminergic agents in animals with electrolytic lesions of the substantia nigra or lateral hypothalamus $11,12,25$. It was suggested that, as the electrolytic lesion is non-specific, it could destroy other inputs necessary to build up dopaminergic stimulus in the striatum, or even damage an afferent striato-pallidal pathway mediating rotatory behavior. Another explanation could be that dopamine receptors become hyposensitive after electrolytic lesion 12 . Other researchers, working with 6-hydroxydopamine, have shown that the direction of rotatory behavior in response to apomorphine depends on the exact place of the lesion, being toward the same side in lesions at the lateral substantia nigra and contralateral in lesions at the medial substantia nigra 29 .

The administration of PLG alone in increasing doses was not followed by rotatory behavior in the model utilized by $\mathrm{us}_{\text {, }}$ the same being found in previous studies suggesting that there is not a direct effect on the nigrostriatal receptors $5,7,21,26,27$. The possibility that after electrolytic lesion direct dopaminergic agonists act on the intact side $\mathbf{2 2}$ prompted us to search for a procedure that could render these receptors more sensitive, enhancing the action of PLG and thus improving its effect. We know from previous studies 9,30 that REM SD is a simple noninvasive method for the induction of supersensitivity of postsynaptic dopaminergic receptors. In the striatal area supersensitivity could be obtained by REM SD in rats with bilateral lesions of the lateral hypothalamic area 3.

In REM SD animals (experiment 2) the administration of either apomorphine or PLG alone was not followed by rotatory behavior, but the association of both drugs in low doses brought rotations to the same side of the lesion, a behavior that disappeared with higher doses of PLG. These findings suggest that the action of PLG is dependent of the presence of dopaminergic agonist (apomorphine, in this study) and of hypersensibility of receptors (induced by REM SD, in this study). The pattern of our results, an inverted U-shaped dose-response relationship, was seen by others using PLG in different doses in apomorphine-induced stereotypy 19, haloperidol-induced catalepsy 18 and stress-induced antinociceptive effect 15.

The observation that PLG has no effect on the binding of $\left({ }^{3} \mathrm{H}\right)$ spiroperidol but enhances the binding of $\left({ }^{3} \mathrm{H}\right)$ apomorphine was taken as an evidence of pre-synaptic action 8 , but the doses were lower than the effective ones of our study. The absence of response to PLG alone was also seen in clinical trials $5,6,14$ and in other experimental studies 7,27 .

An explanation for our results could be that higher doses of PLG might interfere on the motor behavior due to sleepiness and slowness of motor activity. However, it is our impression that PLG acts as a modulator, interacting with dopaminergic agents or modifying the receptors affinity. This hypothesis is strenghtened by the demonstration that PLG enhances the binding of selectice high-affinity agonist $r_{1}$-propyl-nor-apomorphine to D2 receptors in bovine striatal membranes, by enhanctment of interaction of these receptors with guanine nucleotide regulatory proteins 28 .

Acknowledgments - We are grateful to the Department of Psychobiology of Escola Paulista de Medicina for allowing us to use their facilities (animals, laboratories and technical personel).

\section{REF'ERENCES}

1. Alves R, Goyos AG, Carlini EA - Agressiveness induced by marihuana and other psychotropic drugs in REM sleep deprived rats. Pharmacol Biochem Behuv 1:183, 1973.

2. Andén NE, Dalstrom A, Fuxe K, Larsson $\mathbf{K}-$ Functional role of the nigro-neastriatal dopamine neurons. Acta Pharmacol Toxicol 24:263, 1966.

3. Andrade LAF, Lima JGC, Tufik S, Bertolucci PHF, Carlini EA - REM sleep deprivation in an experimental model of Parkinson's disease. Arq Neuro-Psiquiat (Săo Paulo) 45:217, 1987.

4. Barbeau A - Potentiation of levodopa effect by intravenous L-prolyl-L-leucyl-glycine amide in man. Lancet $2: 683,1975$.

5. Barbeau A, Kastin AJ - Polypeptide therapy in Parkinson's disease: a new approach. In Birkmayer W, Hornykiewicz C (eds): Advances in Parkinsonism. Roche Basel, 1976, pg 483.

6. Barbeau A, Roy M, Kastin AJ - Double-blind evaluation of oral I-prolyl-L-leucyl-glycine amide in Parkinson's disease. Can Med Assoc J 114:120, 1976. 
7 Barbeau A, Burnett C, Strother E, Berlanger F, Butterworth RF $\rightarrow$ Investigation of the relationship between some brain peatides and neurotransmitters. Int $J$ Neurol 13:157, 1979 .

8. Bhargava NM $\rightarrow$ The effect of melatonin releasing inhibiting factor, itg metabolites and analogs on (3H) spiroperidol and (3H) apomorphine bindings sites. Gen Pharmacol $14: 609$, 1983.

9. Carlini EA - Psicobiologia do sono. Bol Psiquiat 1:1, 1981.

10. Carlini EA, Dallmeler E, Zelger $\mathrm{KL}$ - Methyleugenol as a surgical anesthesic in rodents. Experientia 37:588, 1980.

11. Costall B, Naylor RJ - A comparison of circling models for the detection of antiparkinson activity. Psychopharmacology 41:57, 1975.

12. Costall B, Marsien CD, Naylor RJ, Psycook CJ - The relationship between striatal and nesolimblc dopamine dysfunction and the nature of circling responses following 6-hydroxydopamine and electrolytic lesions of the ascending dopamine systems of rat brain. Brain Res 118:87, 1976.

13. Cotzias GC, Van Woert MH, Schiffer IM - Aromatic amino acids and modification of parkinsonism. N Engl J Med 276:374, 1967.

11. Ehrensing RM, Kastin AJ - Melanocyte-stimulating-hormone-releage inhibiting hormone as an antidepressant. Arch Gen Psychiat 30:63, 1974.

15. Galina ZH, Kastin AJ - Differential activity of the endogenous antloplate Ty-MIF after various intenstties of stress. Neurnsc Lett $84: 312,1988$.

16. Gerstenbrand F, Binder H, Kosma C, Pusch ST, Reisner TH - Infusiontherapie mit MIF (melanocyte inhibiting factor in Parkinson's disease. Wien Klin Wschr 87:822, 1975.

17. Gerstenbrand F, Powe W, Ransmayr G - New experiences with MIF (PLG) in Parkinson's disease 12t.b World Congress of Neurology Abstracts. Internat Congress Serieg 548. Excerota Medica, Amsterdam, 1981, pg 367.

18. Hara C, Kastin AJ - Acute adminigtration of MIF-1 or Thyr-MIF-1 inhibits haloperidol induced catalepsy in rats. Pharmacol Biochem Behav 24:1785, 1986.

19. Hara C, Kastin AJ - Biphasic effects of MIF-1 and Thyr-MIF-1 on apomorphine-induced stereotypy in rats. Pharmacol Biochem Behsv 25:757, 1986.

20. Kastín AJ, Barbeau A - Preliminary clinical studies with L-prolyl-L-leucyl-glycine amide in Parkinson's disease. Can Med Assnc J 107:1079, 1972.

21. Kostrzewa RM. Kastin AJ, Sobrian SK - Potentiation of apomorphine action in rats by L-prolyl-L-leucyl-glycine amide. Pharmacol Biochem Behav 9:375, 1978.

22. Marshall JF', Ungerstedt $U$ - Supersensitivity to apomorphine folkwing destruction of the ascending dopamine neurons: quantification using the rotationsl model. Fur $J$ Pharmacol 41:361, 1977.

23. Plotnikoff NP - Oxotremorine antagonism by hypothalamic hormone: melanocyte-stimulating hormone release-inhibiting factor (MIF), Proc Soc Exp Biol Med 140:811, 1972.

24. Plotnikoff NP, Kastin AJ, Anderson MS, Sohally AV - Dopa potentiation by a hypothalamic factor. MHS release-inhibiting factor (MIF). Life Scl 10:1479, 1971.

25. Quock RM, Welsh BT - Potentiation of apomorphine-induced rotational behsvior by naloxone. J Pharm Pharmacol 33:11, 1981.

26. Quock RM, Lucas TS, Hartl T _ Potentiation of apomorphine-induced stereotypies by naloxone and L-prolyl-L-Leucyl-glycinamide. Pharmacol Biochem Behav 19:49, 1983.

27. Smith JR, Morgan $M$ - The effects of prolyl-leucyl-glycinamide on drug-induced rotation in lesioned rats. Gen Pharmacol 13:203, 1982.

28. Srivastani LK, Baiva SB, Johnson RL, Mishra RK - Interaction of L-prolyl-L-leucyl-glycinamide with dopamine D2 receptor: evidence for modulation of agonist affinity states in bovine striatal membranes. $J$ Neurochem 50:960, 1988.

29. Thal L. Misinra RK, Gardner EL, Morowitz SG.Varmuza S, Makman MM - Dopamine antagonist binding increases in two behaviorally distinct striatal denervation syndromes. Brain Res 170:381, 1979.

30. Tufik S, Lindsey CJ, Carlini EA - Does REM sleep deprivation induce a supersensitivity of dopaminergic receptors in the rat brain? Pharmacology 16:98, 1978.

31. Ungerstedt $U$ - Striatal dopamine release after anphetamine or nerve denervation revealed by rotational behaviour. Acta Phys Scand 82(suppl 367):49, 1971.

32. Ungerstedt $U$, Arbuthnott $G W$ - Quantitative recording of rotational beharior in rats after 6-hydroxydopamine lesions of the nigro-striatal system. Brain Res 24:183, 1970.

33. Xu DL, Yu WC, Pan GB, Chen SD - Mechanism of action of L-leucyl-glycinamide and its effects on Parkingon's disease, Adv Neurol 45:587, $19: 6$. 